\title{
Pengaturan Kecepatan Motor Switched Reluctance dengan Konverter Asymmetric pada Mode Magnetizing dan Demagnetizing
}

\author{
Tubagus Wasita Febriandi \& Slamet Riyadi \\ Program studi Teknik Elektro, Fakultas Teknik, Universitas Katolik Soegijapranata \\ Semarang, Indonesia \\ andipartvisual@gmail.com, sriyadi7167@gmail.com
}

\begin{abstract}
Abstrak
Saat ini, perkembangan dalam dunia industri cukup pesat. Perkembangan ini dapat dijumpai pada bidang transportasi. Sudah banyak alat transportasi yang telah menggunakan motor modern sebagai tenaga penggeraknya. Salah satu contoh motor modern saat ini adalah Switched Reluctance Motor (SRM). Switched Reluctance motor memiliki kelebihan seperti struktur sederhana dengan konstruksi tanpa magnet permanen di sisi rotor. Untuk menggerakan motor ini, membutuhkan sebuah rangkaian konverter. Salah satu konverter yang digunakan adalah konverter Asymmetric, karena Konverter Asymmetric memiliki kelebihan yaitu teknik kontrol yang mudah dan kecepatan motor dapat diatur. Untuk mengontrol kecepatan motor dapat diatur menggunakan Pulse Width Modulation (PWM). Pada pengontrolan ini lebar PWM dapat berubah dengan mengatur sebuah potensiometer. Pada penelitian ini penulis akan menyajikan hasil pengujian terhadap motor Switched Reluctance dengan menggunakan konverter Asymmetric. Pada sistem pengontrolan menggunakan Pulse Width Modulation (PWM) yang dioperasikan dengan menggunakan mikrokontrol. Hasil pengujian menunjukkan perubahan duty cycle dapat mempengaruhi kecepatan motor Switched Reluctance.
\end{abstract}

Kata Kunci : motor modern, motor switched reluctance, konverter asymmetric, pulse width modulation, duty cycle

\section{Pendahuluan}

Dalam perkembangannya beberapa tahun terakhir ini penggerak motor elektrik sudah sangat maju. Seperti yang diketahui macam-macam penggerak motor elektrik mulai dari motor DC, motor AC, motor stepper dan lain-lain. Salah satu motor yang menjadi pertimbangan yaitu motor Switched Reluctance. Motor Switched Reluctance bukan merupakan penemuan baru karena telah diketahui lebih dari 150 tahun lalu. Pengaplikasian pertama kali motor Switched Reluctance adalah sebagai penggerak lokomotif pada tahun 1842 [1]. Motor Switched reluctance sering dipakai dalam bidang aerospace industry, peralatan tambang, peralatan rumah tangga, dII [2] Motor Switched Reluctance memiliki kelebihan yang melekat seperti struktur sederhana dengan konstruksi non lilitan di sisi rotor.

Konverter menjadi bagian dalam perangkat pensaklaran dari listrik. Karena keterbatasan saklar statis, maka perkembangan motor Switched Reluctance tidak mengalami perubahan. Sehingga beberapa dekade ini dikembangkan kembali dalam elektronika daya $[3,4]$. Untuk menggerakan motor Switched Reluctance salah satunya menggunakan konverter Asymmetric. Konverter Asymmetric dapat mengurangi tegangan ripple pada saklar statis sehingga efisiensi daya dapat ditingkatkan secara efektif. Selain itu dapat beroperasi di bawah siklus kerja saklar statis.[5,6]

Pada makalah ini akan dibahas tentang pengkontrolan motor Switched Reluctance menggunakan konverter Asymmetric dengan mikrokontroller sebagai komponen yang digunakan untuk mengendalikan kecepatan motor yang dikontrol dengan duty cycle.

\section{Metode Penelitian}

Pada makalah ini digunakan motor Switched Reluctance yang digerakkan dengan konverter Asymmetric tiga fasa tanpa pembebanan pada kondisi magnetizing dan demagnetizing.

\subsection{Motor Switched Reluctance}

Motor Switched Reluctance adalah motor listrik yang memiliki konstruksi motor sederhana karena bentuk rotor terbuat dari inti besi. Rotor pada Motor Switched Reluctance memiliki bentuk kutub menonjol atau salient pole $[3,6]$.Oleh karena itu, motor Switched Reluctance sering disebut juga motor dengan kutub ganda (doubly salient pole).

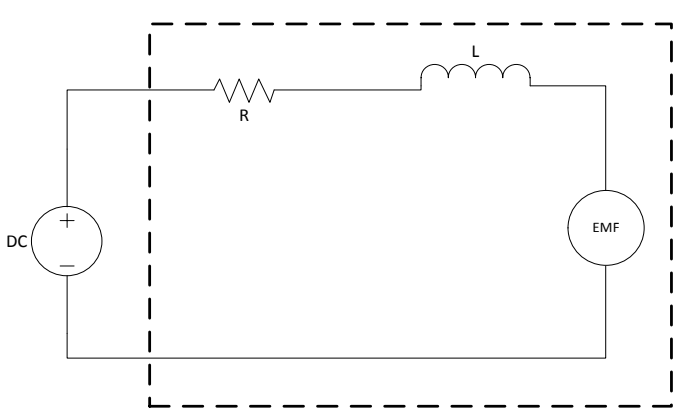

Gambar 1 Rangkaian Ekivalent motor switched reluctance

Dalam motor yang ideal, nilai hambatan $(\mathrm{R})$ adalah nol. Sedangkan motor akan berputar 
dengan Electro Motive Force (EMF) yang hampir sama dengan tegangan yang diberikan. Di dalam sistem operasi motor terdapat EMF balik. EMF balik adalah tegangan balik yang dihasilkan oleh belitan motor Switched Reluctance ketika berputar.

Persamaan tegangan motor Switched Reluctance adalah berikut :

$V=i \cdot R+\left(\frac{d \varphi}{d i}+\frac{d i}{d t}\right)+\left(\frac{d \varphi}{d \varphi}+\frac{d \varphi}{d t}\right)$

Persamaan torsi pada motor Switched Reluctance adalah sebagai berikut:

$T(\varphi, i)=\frac{1}{2} i^{2} \frac{d L(\varphi)}{d \varphi}$

\subsection{Topologi Konverter Asymmetric}

Konverter Asymmetric memiliki 6 saklar statis dan 6 dioda. Konverter Asymmetric pada motor Switched Reluctance memiliki cara kerja sebagai pengaturan pensaklaran on atau off pada saat konfigurasi tertentu [7]. Konverter ini memiliki dua mode operasi pada saat magnetizing dan demagnetizing. Pada gambar 2 dapat dilihat skema konverter Asymmetric.

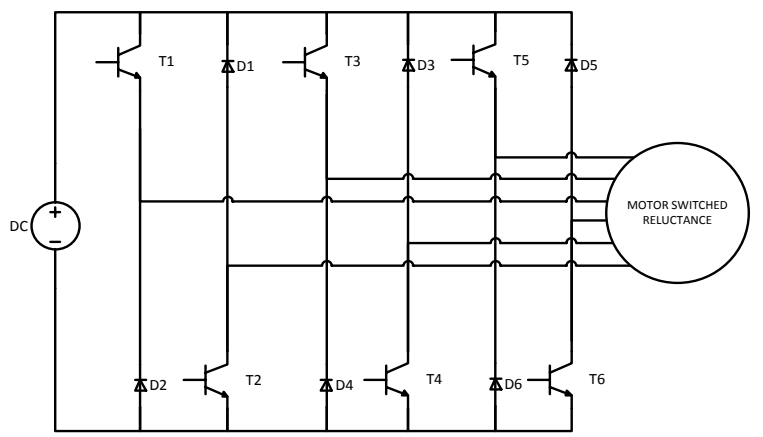

Gambar 2 Skema Konverter Asymmetric

Mode Operasi

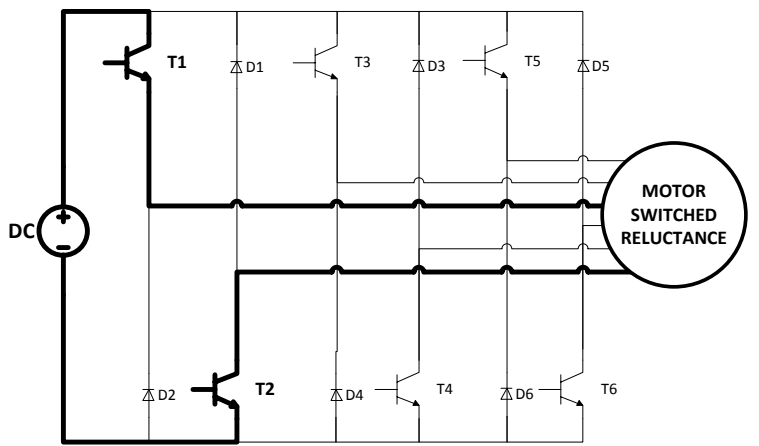

Gambar 3 Mode Magnetizing konverter Asymmetric

Pada saat T1 dan T2 menyala, arus mengalir dari sumber tegangan ke fasa $A$ pada belitan motor sehingga motor pada kondisi magnetizing [8]. Terlihat pada gambar 3 .

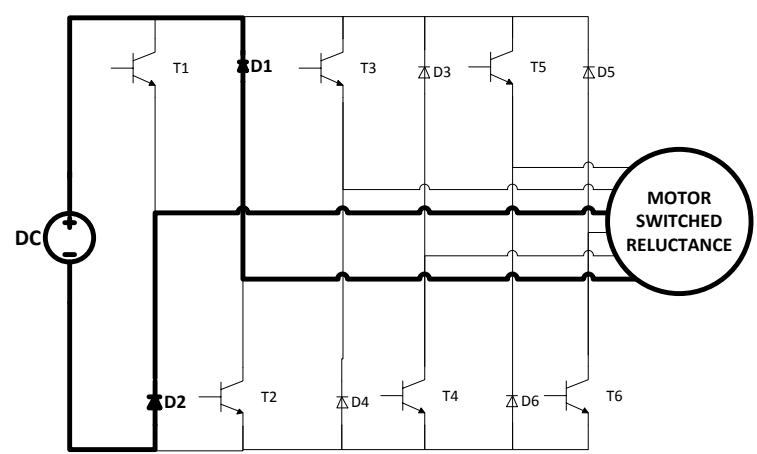

Gambar 4 Mode Demagnetizing konverter Asymmetric

Energi yang tersimpan pada belitan motor dibuang melewati fase A dalam kondisi T1 dan T2 off, saat mode ini tegangan dibuang melewati dioda D1 dan D2 sehingga motor pada kondisi demagnetizing [8]. Terlihat pada gambar 4.

\subsection{Pulse Width Modulation ( PWM )}

Pulse Width Modulation (PWM) adalah suatu cara atau konsep untuk mengatur lebar sempit suatu pulsa [9]. Cara untuk mengaturnya adalah dengan membandingkan sinyal carrier dengan sinyal modulasi, makin besar sinyal modulasi maka sinyal makin lebar, sebaliknya makin kecil sinyal modulasi maka sinyal makin rapat [10]. Pada gambar 5 dibawah ini akan ditampilkan skema duty cycle.

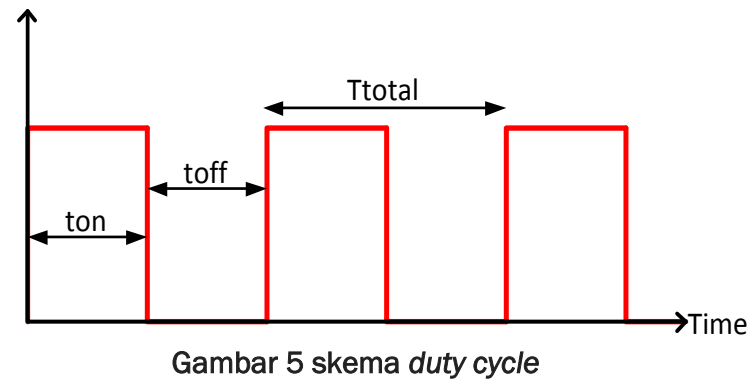

Pada sinyal diatas bisa dituliskan dengan persamaan:

$\mathrm{T}_{\text {total }}=\mathrm{t}_{\text {on }}+\mathrm{t}_{\text {off }}$

$d=\frac{t_{\text {on }}}{T_{\text {total }}}$

Vout $=\frac{t_{\text {on }}}{T_{\text {total }}} \times V$ in

\section{Hasil dan Pembahasan}

Pada makalah ini akan ditampilkan hasil simulasi, penjelasan tentang prototype alat dan hasil pengujian prototype nya. 


\subsection{Simulasi}

Simulasi dilakukan menggunakan perangkat lunak PSIM. Simulasi dilakukan dengan nilai duty cycle yaitu 50\%, 75\% dan 100\% hasil simulasi di tampilkan pada penjelasan berikut. Hasil simulasi keluaran PWM pada duty cycle 50\% ditunjukan pada gambar 6 , duty cycle $75 \%$ pada gambar 7 dan duty cycle $100 \%$ pada gambar 8 .

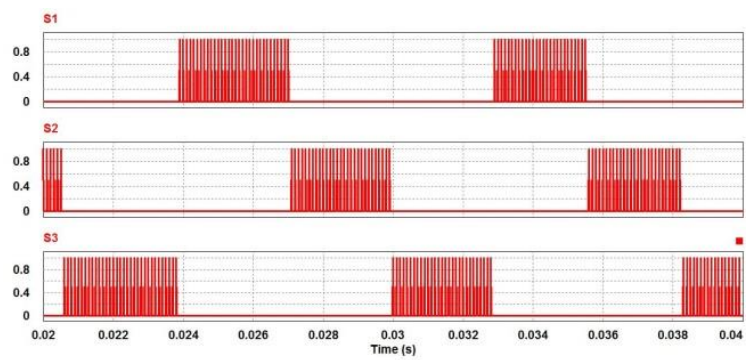

Gambar 6 Hasil simulasi keluaran PWM pada duty cycle $50 \%$
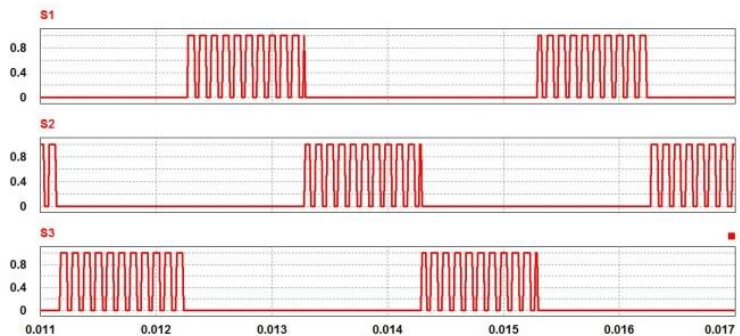

Gambar 7 Hasil simulasi keluaran PWM pada duty cycle $75 \%$
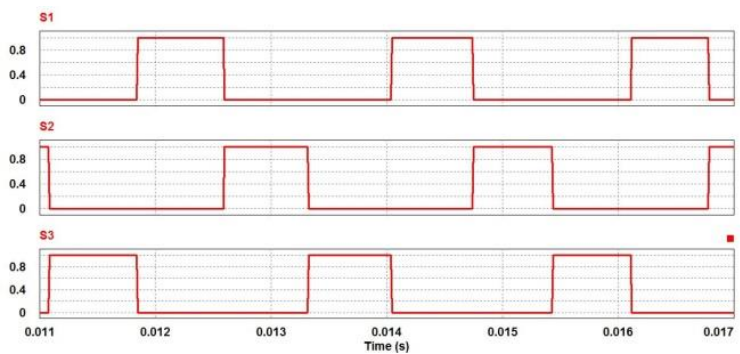

Gambar 8 Hasil simulasi keluaran PWM pada duty cycle $100 \%$

Dibawah ini adalah hasil simulasi tegangan keluaran antar fasa $\left(\mathrm{V}_{\mathrm{ab}}, \mathrm{V}_{\mathrm{bc}}, \mathrm{V}_{\mathrm{ca}}\right)$ pada duty cycle $50 \%$ ditunjukan pada gambar 9 , duty cycle $75 \%$ pada gambar 10 dan duty cycle $100 \%$ pada gambar 11. Perbandingan sinyal tegangan antar fasa pada simulasi terlihat bahwa semakin kecil duty cyclenya maka bentuk sinyal arusnya lebih lebar.

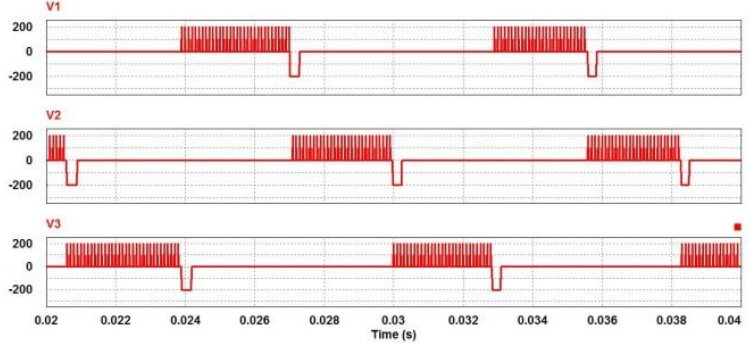

Gambar 9 Hasil simulasi tegangan antar fasa pada duty cycle $50 \%$

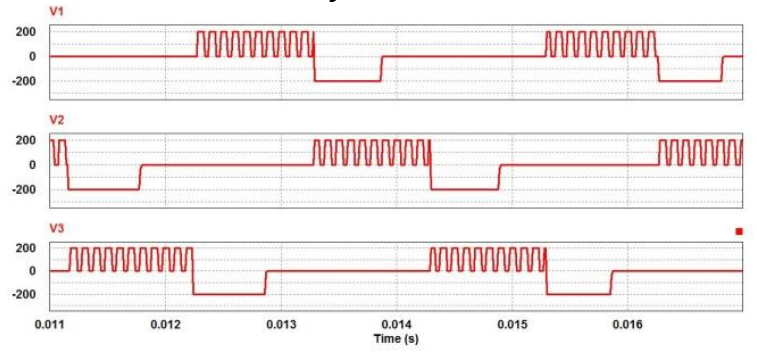

Gambar 10 Hasil simulasi tegangan antar fasa pada duty cycle $75 \%$

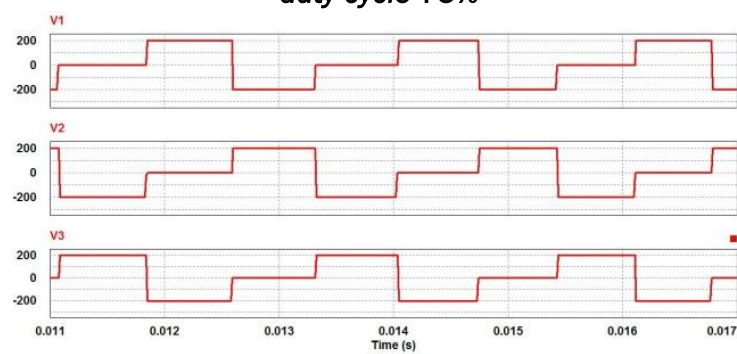

Gambar 11 Hasil simulasi tegangan antar fasa pada duty cycle $100 \%$

Di bawah ini akan ditampilkan hasil simulasi arus keluaran antar fasa ( $\mathrm{l}_{\mathrm{ab}}, \mathrm{I}_{\mathrm{bc}}, \mathrm{I}_{\mathrm{ca}}$ ) pada duty cycle $50 \%$ ditunjukan pada gambar 12 , duty cycle $75 \%$ pada gambar 13 dan duty cycle $100 \%$ pada gambar 14. Perbandingan sinyal arus antar fasa pada simulasi terlihat bahwa semakin kecil duty cyclenya maka bentuk sinyal arusnya lebih lebar.

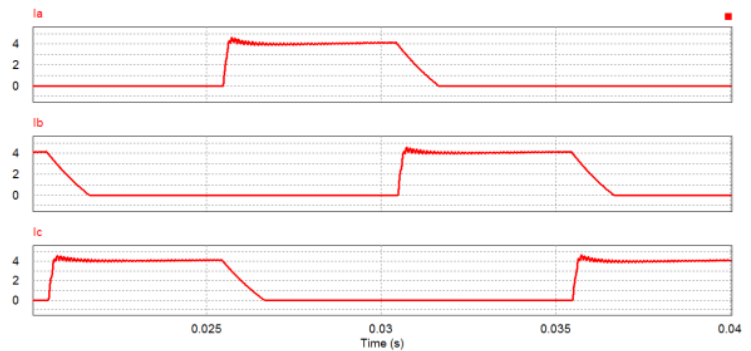

Gambar 12 Hasil simulasi arus antar fasa pada kondisi duty cycle $50 \%$ 


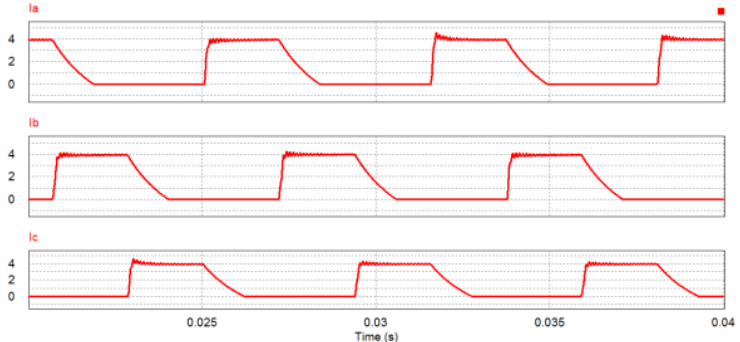

Gambar 13 Hasil simulasi arus antar fasa pada kondisi duty cycle $75 \%$

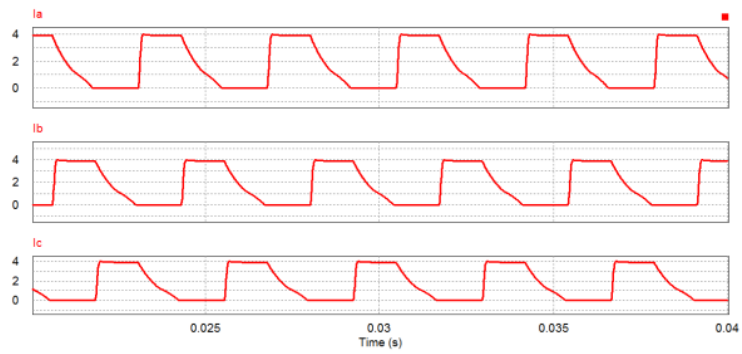

Gambar 14 Hasil simulasi arus antar fasa pada kondisi duty cycle $100 \%$

Di bawah ini akan ditampilkan hasil simulasi kecepatan pada duty cycle 50\% ditunjukan pada gambar 15 , duty cycle $75 \%$ pada gambar 16 dan duty cycle $100 \%$ pada gambar 17 . Perbandingan sinyal arus antar fasa pada simulasi terlihat bahwa semakin kecil duty cyclenya maka bentuk sinyal arusnya lebih lebar.

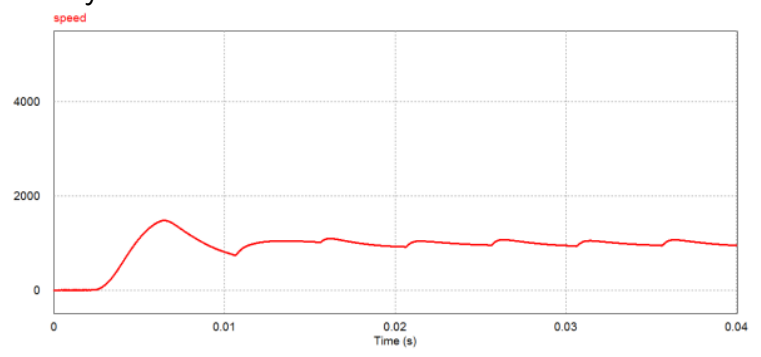

Gambar 15 Hasil simulasi kecepatan kondisi duty cycle $50 \%$

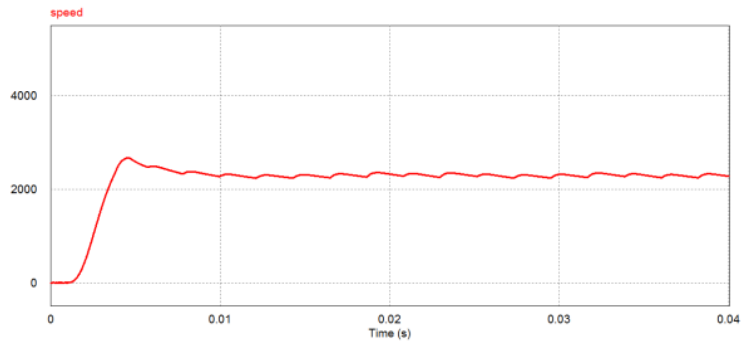

Gambar 16 Hasil simulasi kecepatan kondisi duty cycle $75 \%$

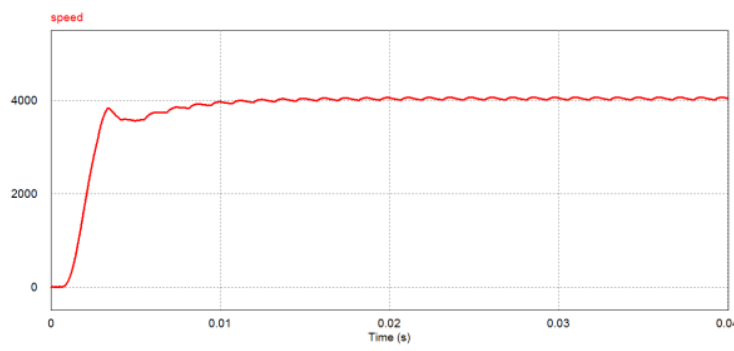

Gambar 17 Hasil simulasi kecepatan kondisi duty cycle $100 \%$

\subsection{Hasil Pengujian}

Untuk mendukung hasil simulasi dan analisi maka dilakukan pengujian. Pengujian ini menggukan prototype disajikan pada gambar 18 . Pada prototype tersebut terdapat motor Switched Reluctance yang akan diendalikan menggunakan Konverter jenis Asymmetric. Duty cycle yang digunakan adalah sama seperti yang digunakan pada simulasi sebagai pendukung kebenaranya.

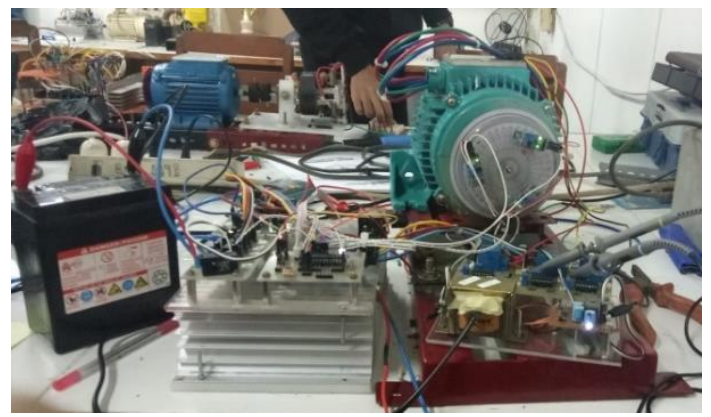

Gambar 18 prototype motor switched reluctance dengan konverter asymmetric

Di bawah ini adalah hasil tegangan keluaran PWM yang diatur pada duty cycle 50\%, 75\% dan $100 \%$ dalam kondisi motor Switched Reluctance motoring pada gambar 19, gambar 20 dan gambar 21. Dapat dilihat bahwa sinyal tegangan keluaran PWM selain berpengaruh pada duty cyclenya juga berpengaruh pada lebar sinyal keluaran pulsanya.

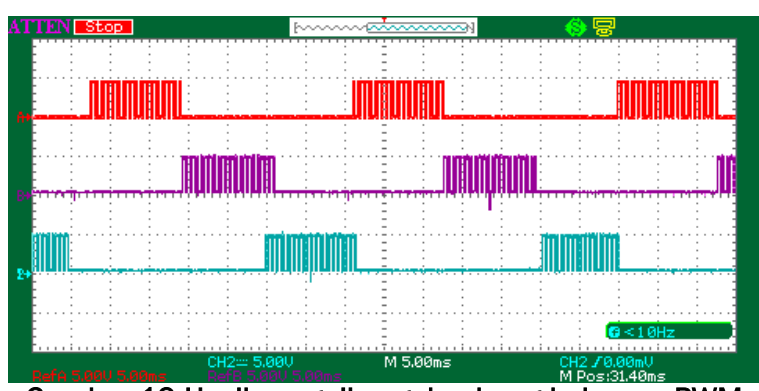

Gambar 19 Hasil pengujian gelombang keluaran PWM pada duty cycle $50 \%$ 


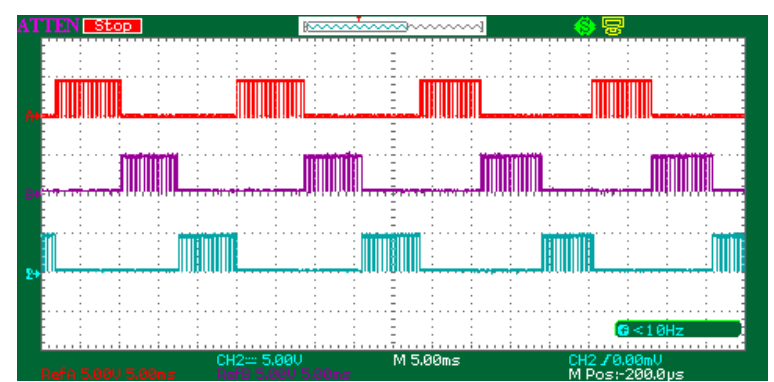

Gambar 20 Hasil pengujian gelombang keluaran PWM pada duty cycle $75 \%$

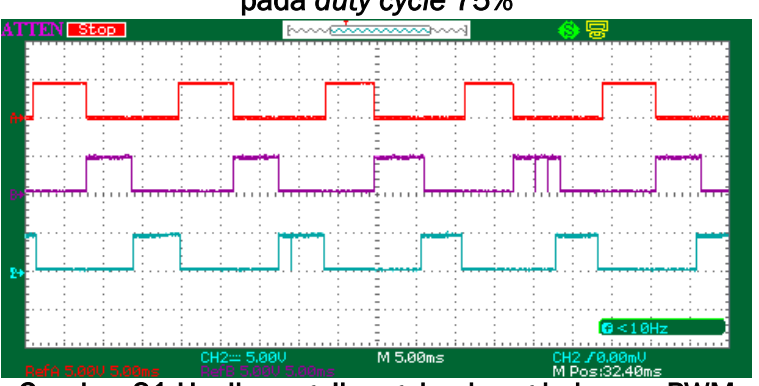

Gambar 21 Hasil pengujian gelombang keluaran PWM pada duty cycle $100 \%$

Di bawah ini akan ditampilkan hasil pengujian pada motor Switched Reluctance dalam kondisi motoring yang menghasilkan sinyal tegangan antar fasa dengan duty cycle 50\%, 75\% dan 100\% pada gambar 22, gambar 23 dan gambar 24. Perbandingan sinyal tegangan antar fasa terlihat bahwa semakin kecil duty cyclenya maka bentuk sinyal arusnya lebih lebar.

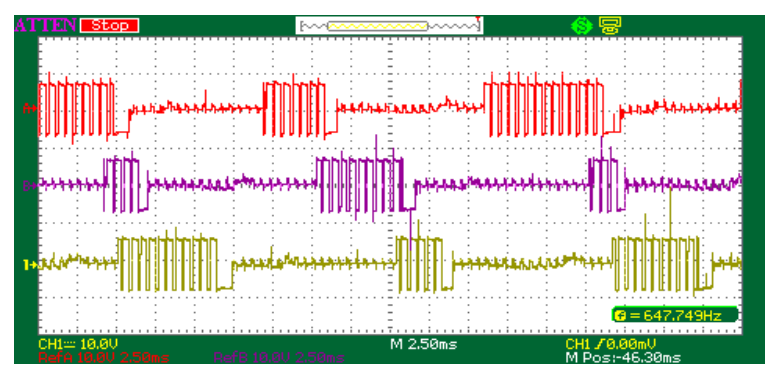

Gambar 22 Hasil pengujian keluaran tegangan antar fasa $\left(\mathrm{V}_{\mathrm{ab}}, \mathrm{V}_{\mathrm{bc}}, \mathrm{V}_{\mathrm{ca}}\right)$ duty cycle $50 \%$

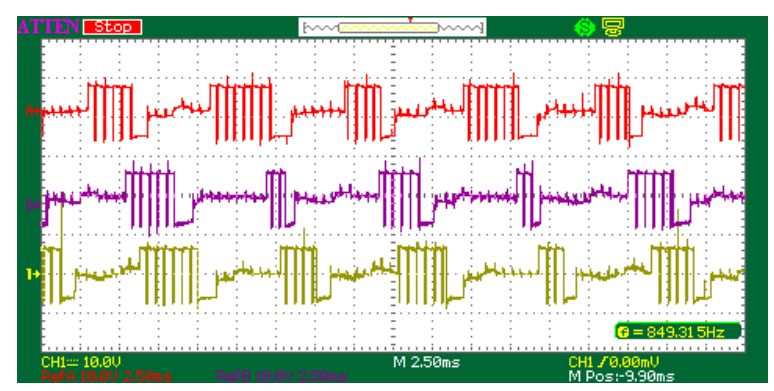

Gambar 23 Hasil pengujian keluaran tegangan antar fasa $\left(\mathrm{V}_{\mathrm{ab}}, \mathrm{V}_{\mathrm{bc}}, \mathrm{V}_{\mathrm{ca}}\right)$ duty cycle $75 \%$

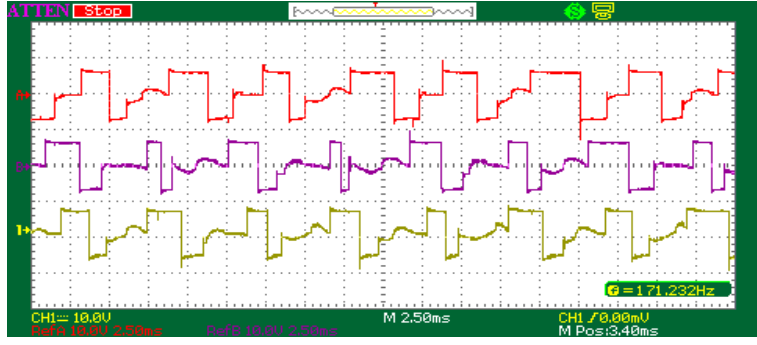

Gambar 24 Hasil pengujian keluaran tegangan antar fasa $\left(\mathrm{V}_{\mathrm{ab}}, \mathrm{V}_{\mathrm{bc}}, \mathrm{V}_{\mathrm{ca}}\right)$ duty cycle $100 \%$

Di bawah ini akan ditampilkan hasil pengujian pada motor Switched Reluctance dalam kondisi motoring yang menghasilkan sinyal arus antar fasa dengan duty cycle 50\%, 75\% dan 100\% pada gambar 25, gambar 26 dan gambar 27 . Perbandingan sinyal arus antar terlihat bahwa semakin kecil duty cyclenya maka bentuk sinyal arusnya yang mengisi antar fasanya semakin melebar.

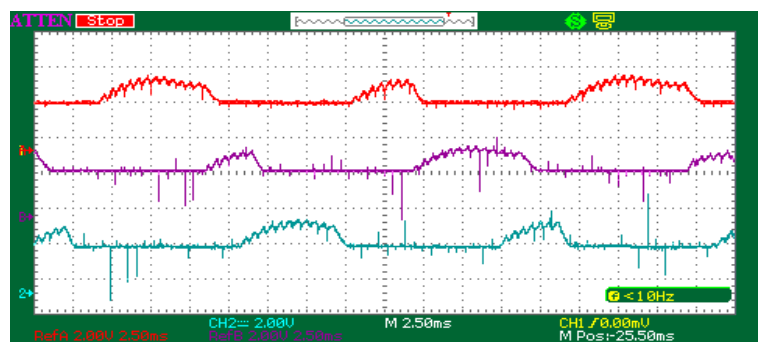

Gambar 25 Hasil pengujian keluaran arus antar fasa ( $\mathrm{lab}_{\mathrm{ab}} \mathrm{I}_{\mathrm{bc}}, \mathrm{I}_{\mathrm{ca}}$ ) duty cycle $50 \%$

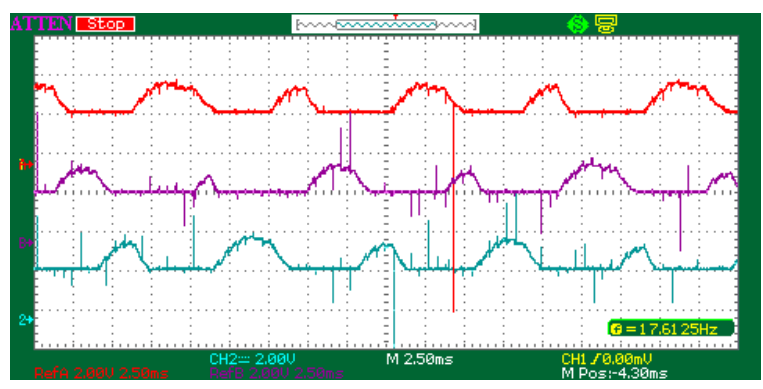

Gambar 26 Hasil pengujian keluaran arus antar fasa (lab, $\mathrm{l}_{\mathrm{bc}}, \mathrm{I}_{\mathrm{ca}}$ ) duty cycle $75 \%$

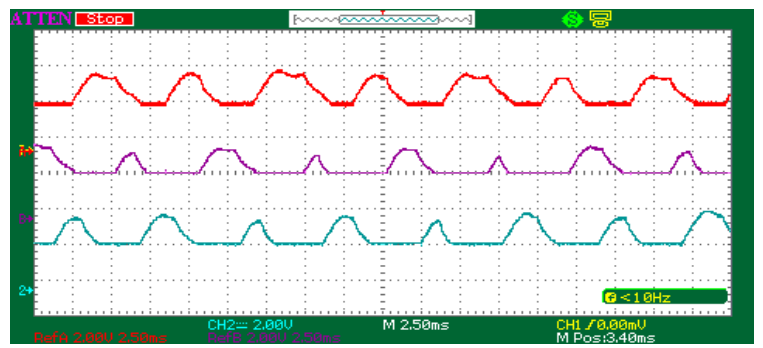

Gambar 27 Hasil pengujian keluaran arus antar fasa (lab, $\mathrm{l}_{\mathrm{bc}}, \mathrm{I}_{\mathrm{ca}}$ ) duty cycle $100 \%$ 
Kecepatan motor Switched Reluctance dapat diatur menggunakan duty cycle. Setelah melakukan pengujian prototype dan telah mendapatkan hasil, kemudian akan ditampilkan hasil kecepatan yang diukur dengan menggunakan tachometer. Hasil kecepatan dapat dilihat pada gambar 28, gambar 29 dan gambar 30.

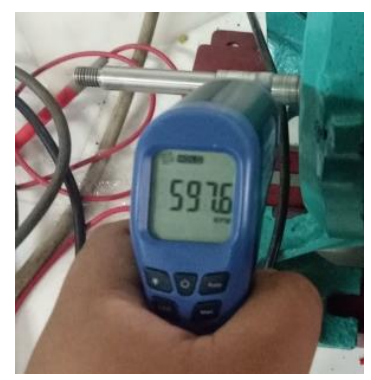

Gambar 28 Hasil pengujian kecepatan SRM pada kondisi duty cycle $50 \%$

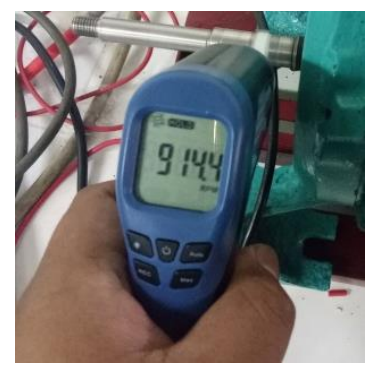

Gambar 29 Hasil pengujian kecepatan SRM pada kondisi duty cycle $75 \%$

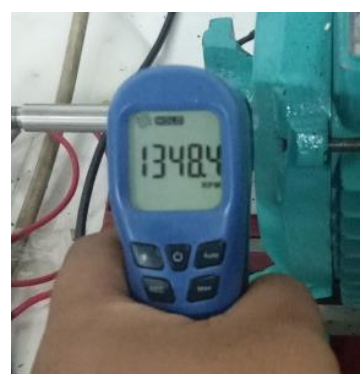

Gambar 30 Hasil pengujian kecepatan SRM pada kondisi duty cycle $100 \%$

Sebagai pendukung dari hasil yang diperoleh yaitu sebagai perbandingan antara posisi duty cycle dengan kecepatan yang ada. Ditampilkan pada tabel 1 dibawah ini.

Tabel 1 Parameter hasil Penelitian

\begin{tabular}{|l|l|l|l|}
\hline No & Kondisi & $\begin{array}{r}\text { Duty } \\
\text { Cycle }\end{array}$ & $\begin{array}{c}\text { kecepatan } \\
\text { (rpm) }\end{array}$ \\
\hline 1 & $\begin{array}{l}\text { Potensio } \\
\text { Penuh }\end{array}$ & $100 \%$ & 1348.8 \\
\hline 2 & $\begin{array}{l}\text { Potensio } \\
3 / 4\end{array}$ & $75 \%$ & 914.4 \\
\hline 3 & $\begin{array}{l}\text { Potensio } \\
1 / 2\end{array}$ & $50 \%$ & 597.6 \\
\hline
\end{tabular}

\section{Kesimpulan}

Pada pengujian ini dapat ditunjukkan bahwa pengaturan kecepatan motor Switched Reluctance dengan konverter Asymmetric pada mode magnetizing dan demagnetizing menggunakan kontrol PWM dapat dibuktikan, bahwa semakin besar duty cyclenya akan berpengaruh pada arus dan tegangan yang semakin tinggi. Sebaliknya jika semakin kecil duty cyclenya akan berpengaruh pada arus dan tegangan yang semakin rendah.

\section{Nomenklatur}

Daftar nomenklatur

$$
\begin{aligned}
\mathrm{V} & =\text { Tegangan } \\
\mathrm{i} & =\text { Arus } \\
\mathrm{R} & =\text { Hambatan } \\
\mathrm{L} & =\text { Induktor } \\
\phi & =\text { Fluksi } \\
\mathrm{T} & =\text { Torka motor } \\
\mathrm{t}_{\mathrm{on}} & =\text { Ketika Pulsa "High" } \\
\mathrm{t}_{\text {off }} & =\text { Ketika Pulsa "Low" } \\
\mathrm{d} & =\text { duty cycle }
\end{aligned}
$$

\section{Daftar Pustaka}

[1] K. Vijayakumar, R. Karthikeyan, R. Arumugam, and K. N. Srinivas, "Switched Reluctance Motor Modeling, Design, Simulation, and Analysis: A Comprehensive Review." IEEE TRANSACTIONS ON MAGNETICS, vol. 44, no. 12, december 2008

[2] M. Asgar, E. Afjei, A. Behbahani, A. Siadatan. “ A 12/8 Double-Stator Switched Reluctance Motor for Washing Machine Application". IEEE 3-4 February 2015.

[3] E. Afjei, A. Siadatan, and M. Rafiee. "Construction of a Low Cost Asymmetric Bridge Converter for Switched Reluctance Motor Drive." IEEE, 2013.

[4] Ryan Agung Triaji, Nasrun Harianto, Syahrial Syahrial. "Analisis Motor Reluktansi Tipe Switched Reluctance Motor Dengan Sumber Tiga Fasa." Jurnal Teknik Elektro "REKAELKOMIKA". Vol.2 No 4 (2014)

[5] Jin-Woo Ahn, Ph.D, "Switched Reluctance Motor." Torque Control ISBN 978-953-307428-3, published 10, February, 2011.

[6] Ankit P. Khedkar, P. S. Swami, "Comparative Study of Asymmetric Bridge and Split AC Supply Converter for Switched Reluctance Motor." ICCPEIC, 2017. 
[7] M. Asgar, E. Afjei, A. Siadatan, Ali Zakerolhosseini. "A New modified Asymmetric Bridge Drive Circuit Switched Reluctance Motor." IEEE, 2009.

[8] Souvik Ganguli, "Analysis of An Asymmetric Bridge Converter for SRM Drives Using PSPICE Simulation." October-December, 2011

[9] B.M. Shihab, H.S. Che, W. P. Hew. “ Symmetrical Six-Phase PWM Methods Using Similar and Dissimilar Zero-sequence Signals
Injection." $4^{\text {th }}$ IET Clean Energy and Technology Conference (CEAT 2016)

[10] Zhang X., Wang B., Lin Y. \& Zhang R. Application research of PWM Inverter in the cascade speed control system of InnerFeedback motor. 2009 9th International Conference on Electronic Measurement \& Instruments." 